\title{
The Internationalization of Industrial Relations in Europe: Prospects and Problems
}

Wolfgang Streeck: The Internationalization of Industrial Relations in Europe: Prospects and Problems. In: Politics and Society 26(4), 429-460 (1998). Sage Publications

The original publication is available at the publisher's web site: http://dx.doi.org/10.1177/0032329298026004002

\section{WOLFGANG STREECK}

European industrial relations are rapidly internationalizing; internationalization, however, is not necessarily denationalization. Even as European integration accelerates, national politics and industrial relations will, for better or worse, remain the principal arenas for the social regulation of work and employment in Europe. This is because European integration has over more than four decades come to be firmly defined as a process of economic liberalization by international means: of the opening up of national economies through internationally negotiated expansion of markets beyond national borders. Associated with this was the evolution of a now well-established pattern of selective supranational centralization and institution building, which dedicates supranational institutions primarily to purposes of market making while leaving social regulation essentially a national responsibility. As a result, social regulation becomes itself exposed to competitive market pressures, which further advances liberalization.

Although the governance of European industrial relations is not about to be handed over to supranational institutions, the present paper argues that national institutions are unlikely to converge on a common pattern of "best practice" or

Revised and expanded version of the closing address at the European Regional Congress of the International Industrial Relations Association, Dublin, August 26-29, 1997. Parts of the paper were presented as a lecture at the International Studies and the Western European Area Studies programs at the University of Wisconsin-Madison, September 24, 1997. I am grateful to Werner Eichhorst, Ute Knaak, and Philip Manow for comments and criticism. Responsibility for any remaining flaws rests with the author.

POLITICS \& SOCIETY, Vol. 26 No. 4, December 1998 429-459

(C) 1998 Sage Publications, Inc. 
whatever, in response to market pressures or as a result of supranational reregulation. Rather, it claims that neither integration nor convergence theory are well equipped to deal with the complexities of institutional change in interdependent national systems that are embedded in a common market and connected through common supranational institutions sustaining that market. In particular, the paper undertakes to explore some of the emerging characteristics of an institutional configuration in which industrial relations are governed by an international multilevel system, a configuration that will shape European industrial relations and social policy for a long time to come. It also explores the potential for both a politicization of supranational governance, moving social regulation from the national to the European level, and social reconstruction within national states that are nested into an increasingly competitive European state system.

\section{INTEGRATION AS LIBERALIZATION}

By the time of the Treaty of Rome, the preferred approach for the integration of the European economy, and presumably European society, had become the integration of markets, and no longer of planning authorities on the older model of the European Community for Coal and Steel. ${ }^{1}$ Market integration required primarily the removal of trade barriers widely defined. To ensure the lasting compliance of national governments, an initially uncertain measure of institutional integration was required under which member states had to subject themselves to the authority of supranational institutions. But it soon became apparent that an integrated international market economy could be instituted and maintained well short of instituting an integrated supranational state. ${ }^{2}$ Ultimately, this made possible a lasting dissociation of international economic integration from supranational state building. As economic integration became identical with liberalization, it became ipso facto compatible with national sovereignty, reducing the institutions of integrated Europe to the role of a supranational liberalization engine: while extricating the European economy from national political control, by turning it into an international economy, they at the same time extricate it from political control generally as the international economy that they construct has no integrated state confronting it. ${ }^{3}$ The elective affinity between nationalism and liberalism that has deeply shaped the logic of European integration ${ }^{4}$ has many facets. Continued national fragmentation of political sovereignty in an internationally integrated market accords with economic interests that would have to fear the interventionist tendencies of a unified supranational state. Vice versa, limiting economic integration to market making, with the institutional minimalism at the supranational level that this makes possible, is in the interest of those that have a stake in the survival of national institutions and national sovereignty. Just as integration-defined-asliberalization gives the nation-state a further lease on life, national fragmentation of sovereignty and intergovernmentalism favor liberalization as the privileged method of European integration. In fact, arguably economic interests and 
institutions differ so widely between European countries, and national identities continue to be so firmly established, that anything like supranational state building was probably always unrealistic for this reason alone, a priori establishing international liberalization as the principal method of integration.

As has often been shown, negative integration through the removal of barriers to trade and mobility is generally easier for sovereign countries to agree to than positive integration through the building of common institutions. ${ }^{5}$ It also had the support of powerful forces inside national systems keen on pushing back government intervention, especially in the 1980s and 1990s. These frequently included national governments themselves that were no longer willing or able to take responsibility for their economies. To them, the depoliticization of the economy that is brought about by international liberalization represented an opportunity to withdraw from their postwar economic responsibilities, without having to turn them over to an international super-state potentially contesting their political monopoly. In any case, once the process of international market expansion had started, it was clearly in most countries' interest not to be excluded from it, and this overrode concerns, where they existed at all, about the liberalization that came with it. Especially in the formative years of the integration process, given the obvious economic benefits of trade expansion and the equally obvious impediments to supranational state formation, the liberalization path of European integration was never seriously in question.

Today, European integration has resulted in a complex new configuration of national and international institutions and markets. National political systems, far from having disappeared, have come to be enveloped in a unified market, on one hand, and in international market-enforcing institutions, on the other. With respect to the latter, while popular and state sovereignty have remained vested in a multitude of nation-states, economic governance has increasingly been taken over by integrated supranational agencies charged with, for example, the enforcement of a joint competition regime ${ }^{6}$ and, soon to come, the administration of a common currency. Their insulation from political pressures, enabling them to operate in the mode of technocratic regulatory authorities, simultaneously protects the political monopoly of the nation-states and enshrines the liberal character of the integrated economy, as does the centralization of market-making institutions compared to the decentralization and fragmentation of the traditional institutions of political sovereignty. The result is a multilevel political economy, where politics is decentralized in national institutions located in and constrained by integrated competitive markets extending far beyond their territorial reach, and where supranationally centralized institutions are primarily dedicated to implementing and maintaining those markets.

That European integration as we know it amounts in its core to economic liberalization is closely associated with its constitutive mismatch between the reach of political sovereignty and the size of the integrated market and with the 
decentralization of politics coinciding with the centralization of market making. It is also associated with the embedding of national political institutions in an international market that exposes them to pressures of regime competition, which in turn both forces and enables national governments to push back demands for political "distortion" of that market. European integration has in this way injected a hitherto unknown degree of competition, not just into the European economy, but also into the exercise of public authority over it, which may in fact be its most important contribution to liberalization. There are strong interests vested in the emerging European pattern of institutional centralization and decentralization, international and national politics, technocratic and political governance, and market-making and market-constraining rules. ${ }^{8}$ Given the long historical evolution of this pattern, as well as its confirmation in the Treaties of Maastricht and Amsterdam, it seems misleading to conceive of the multilevel polity of integrated Europe as of a federal system-in-waiting; that is, of an institutional superstructure that will ultimately develop a unified capacity to suspend internal competition in the service of social cohesion. In reality, the multilevel political system of the European Union seems by now to have firmly established itself as a liberalization regime dedicated to enhancing competition and freeing market forces from political interference, and indeed one that has become sufficiently settled to be largely self-reproductive and capable of conditioning its own further evolution.

In trying to understand the institutional logic of European integration, it is important not to confuse liberalization with deregulation. While international liberalization in particular does require the removal of a large body of rules, especially national rules obstructing free trade, usually new rules must be created to make the new international markets work. These include, for example, an international competition regime that must outlaw "state aids" by participating countries to national industries and force countries to allow foreign competition to enter formerly closed sectors. Also required may be centralized regulation to prevent market failure, from standardization to product safety. As Steven $\mathrm{Vogel}^{9}$ has shown for liberalization generally, and Giandomenico Majone ${ }^{10}$ for the European Union, freer markets often come with more rules and sometimes with large regulatory machineries. That European integration is closely associated with extensive rule making is therefore quite compatible with the suspicion that it in its core a process of liberal market making.

Moreover, liberalization also calls forth demands for social reregulation, to enable individuals and communities to cope with the uncertainties of free markets and stabilize their social existence in dynamically changing economic conditions. Regulation and reregulation are particularly closely intertwined in labor markets, owing to the peculiar characteristics of labor as a commodity. Free labor markets require what Marshall ${ }^{11}$ has called "civil rights" of citizenship, allowing individuals voluntarily to engage in contractual relations. But as the latter expand, their transforming impact on social life and the distinctive logic of social structures and 
norms of social justice give rise to countermovements for social protection, ${ }^{12}$ deploying "politics against markets"13 and making social reregulation almost as much part of the liberalization of labor markets, although a dialectical one, as deregulation and regulation.

Industrial relations have therefore always, although to varying degrees, been governed by rules, not just of contract, but also of status: ${ }^{14}$ rules that impose rights and obligations on contracting parties that they are not allowed to modify by mutual agreement. Rules of status, or "industrial" and "social" rights, as Marshall calls them, protect social integration by limiting the reach of contract and the market. As they cannot by definition spring from the free play of market forces, they must be created by public intervention. It is true that in industrial relations, market-constraining intervention, or reregulation, is not easily distinguished from market-making intervention, or regulation, and not just because both depend on public power. In labor markets, the prevention of market failure and the promotion of social justice may sometimes blend into one another, as strongly felt injustice on the part of workers may detract as much or more from the efficiency of markets and organizational hierarchies as, for example, lack of information or contract enforcement. To this extent, what is an efficient organization of the labor market depends in part on what is perceived to be a fair organization. This is why it is sometimes possible rhetorically to defend redistributive intervention in labor markets as a means of enhancing economic efficiency, or social reconstruction as a contribution to market making. ${ }^{15}$ But this does not abolish the generic distinction between intervention expanding the range of market relations and intervention limiting market relations and embedding them in social constraints.

In the multilevel institutional structure of integrated Europe, pressures for the political defense of social cohesion tend to be deflected to national systems and are mostly compartmentalized in them, given that supranational institutions are far removed from and structurally desensitized to such pressures. Obviously, the extent to which such pressures can be satisfied at the national level is strictly circumscribed by internationally institutionalized competition rules and marketdriven regime competition. But from this it does not follow that with the progress of European integration, social protection will ultimately become a centralized supranational responsibility. Although the capacities for national reregulation in the European multilevel polity are clearly inferior to what they were in the more self-contained nation-state of the postwar period, all this may mean is that in the way integrated Europe has come to be constituted, the balance of forces between market expansion and social reconstruction may for a long time have shifted away from the latter.

Summing up so far, the liberal bias of Europe's multilevel polity resides in the fact that its central level is an international political arena governed by intergovernmental relations and technocratic agencies, while politics proper is confined to a set of nation-states located on its lower, decentral level. The result is a wide gap 
in the development of market-making and market-correcting institutions in the political economy of integrated Europe. Intergovernmentalism and technocratic regulation are more congenial to negative integration and the expansion of markets and competition than to positive integration and the social containment of competition. The resulting policy predispositions and the policy legacies of the successful liberalization projects of the past are defended by strong interests, strengthened in turn by the way in which the European institutional cards are stacked: national interests in preserving the nation-state, which are congenial to a liberalization mode of integration, as well as economic interests in an unfettered free international market, which are best served if national sovereignty is not replaced with supranational sovereignty.

While institutions make some outcomes more probable than others, however, they do not determine them. Outcomes and, indeed, institutions themselves can be contested. This is clearly the case in Europe, where attempts have never ceased to politicize supranational governance and push social reregulation upwards from the national to the European level. Such attempts may try to capitalize on practical uncertainties as to the extent to which political consensus, trust, and legitimacy may be a precondition for an efficient management of markets and organizations -in other words, as to how much social reregulation is required for markets to be viable in a democratic society. Moreover, what precisely the range of practical possibilities is for social reconstruction within nation-states under regime competition is largely unexplored, given the recency of the problem and the continued evolution of the European polity.

\section{EUROPEAN INDUSTRIAL RELATIONS AS A MULTILEVEL SYSTEM}

The character of the European integration process, stuck in the middle between intergovernmentalism and supranational state formation, ${ }^{16}$ has profound consequences for industrial relations in Europe, especially for national industrial relations. Most important, European industrial relations are not about to become identical with supranational industrial relations. European-wide harmonization and centralization of industrial relations are blocked by the same factors that inhibit supranational state formation, as well as by the delay of the latter as such. Any attempt at harmonization faces the problem of wide, historically grown diversity of national institutions, ${ }^{17}$ which not only raises often insurmountable technical difficulties but also leads to harmonization having asymmetrical consequences in different countries; usually this is enough to call forth sufficient opposition to prevent it. Moreover, as to unionization, the inhibiting effects of wide differences in national economic conditions and interests are reinforced by the absence of facilitating state capacity at the European level, which in turn reinforces the primacy of national forms of organization. Unions also lack strong interlocutors at the European level, as employers can best pursue their interests in international liberalization by holding back on supranational organization and negotiation. ${ }^{18}$ 
One implication of this is that the emerging European-level institutions of industrial relations are not about to develop into a replica of a national industrial relations system on a larger scale. Studying them in the way of a look-alike contest, by comparing the Social Dialogue to national corporatist arrangements, ${ }^{19}$ the sectoral dialogues either to industry-wide collective bargaining or to industrial policy boards, ${ }^{20}$ and European works councils to company-level collective bargaining committees or works councils under the German "dual system," leading. Nor does it make much sense to try to identify the national system-the French, the British, the German - that the new European institutions most closely resemble. European institutions of industrial relations will for all practical purposes always coexist with national institutions and perform their functions, whatever they may be, only in interaction with these. Moreover, as national systems are different, that interaction will differ from country to country, and so will the significance for the regulation of the employment relationship of its new European dimension. Far from being about to consolidate into an integrated supranational regime, European industrial relations have developed into a multilevel system that matches and complements the multilevel institutions that have come to govern most of public policy making in Europe.

The dynamics of multilevel industrial relations in an international setting are amazingly complex. In the following, I will briefly and initially explore some of their main facets, without even trying systematically to link them to one another: the pressures for change on national systems under institutional interdependence and economic regime competition; the simultaneous extension and modification of diverse national institutions through international coordination; the substitution of structural convergence by functional equivalence; tendencies for functional convergence in the name of national competitiveness and a general tendency for markets to extricate themselves from institutional distortion; pressures on national systems of industrial relations to externalize social protection from the workplace to an already overburdened public sector; declining institutional capacities at the national level to contain the diversity of institutional arrangements in different firms and sectors and organize solidaristic redistribution between them; and the need for national politics, in the absence of supranational alternatives, to explore the possibilities and, even more, the limits of social protection in national systems embedded simultaneously in competitive markets and market-making international institutions.

National adjustment to competitive interdependence. It has by now become almost commonplace that social protection in Europe will for a long time remain primarily a national matter. ${ }^{22}$ Attempts at harmonization, aimed at establishing common standards and taking them out of the market, have largely been given up in recognition of the limited supranational capacities available for this. But there have also been few examples, if any, of European regulation mandating deregulation of industrial relations at the national level. In some cases, supranational regu- 
lations, like the "Kristoffersen clause" in various European directives, ${ }^{23}$ are specifically designed to preserve the diversity of national institutions. But lack of formal institutional intervention "from above" does not mean that national systems are likely to remain unchanged. At least two sorts of pressures for national adjustment can be identified, one issuing from a changed institutional environment of national industrial relations, and the other from expanded internationalized markets. Both reflect the embedding of national systems of industrial relations in the integrated European political economy. ${ }^{24}$

First, the pattern of selective centralization that is characteristic of European integration has substantially affected the capacities of national industrial relations systems. For example, with monetary policy centralized, fiscal policy in the straitjacket of an international "stability pact," and employment policy internationally defined as a national responsibility, the only remaining way by which countries may be able to match demand and supply in their labor markets may be by enhancing the "flexibility" of the latter, very likely requiring deep changes in industrial relations. While on the surface these will appear to be strictly national choices, they can only be explained in the context of the multilevel governance system in which national systems are contained.

Second, international liberalization has exposed national systems of economic governance to regime competition, in part precisely to the extent that they remained at first unchanged. As markets expand, national institutions find themselves constrained to accommodate market forces beyond their control. In particular, with the attrition of national borders, internationally mobile production factors increasingly have the option of "voting with their feet" if national institutions and their distributive results are not to their liking. ${ }^{25}$ At the very least, the ensuing competition between countries, especially of course for capital, strengthens the voice inside national systems of those capable of abandoning them. ${ }^{26} \mathrm{By}$ changing the balance of power within national institutions, regime competition changes the substance of the policies these generate. In the longer run, the same pressures may lead to institutional reforms aimed at enhancing the "competitiveness" of national regimes. But even without formal reorganization, European integration, by locating national systems of industrial relations in an international market, makes them pay more attention to the demands of "market forces."27

It is important to note that the recasting of national industrial relations by regime competition does not presuppose much actual movement of production factors or production across national borders. ${ }^{28}$ Given the vital importance for national economic well-being of internationally mobile supply and demand, the mere potentiality of such movement and the credible threats it makes possible are enough to tip the balance. Nor does regime competition require wide differences in wages or production costs, like those between developed and developing countries; in fact, it seems more common between countries of comparable productivity-where its main effect, rather than actual cross-border mobility, is the 
elimination of slack resulting in higher competitiveness, if not productivity, in each of the countries concerned. ${ }^{29}$

Supranational coordination of national diversity. Within the multilevel European industrial relations regime, supranational intervention in national systems is typically restricted to their coordination. The model seems to be the European Union's successful legislation on mobility of labor, which obliged countries to abolish impediments to cross-national movement while otherwise leaving national labor market regimes untouched. ${ }^{30} \mathrm{~A}$ recent example of this approach in industrial relations is the European Works Councils Directive. ${ }^{31}$ Avoiding interference with existing national systems of workplace representation, the directive supplements them with largely firm-specific representation arrangements for nondomestic European workers at the headquarters of multinational companies. Normally, but not necessarily, these provide for a common European minimum of representation to workers in European subsidiaries outside the company's home country. Instead of trying to harmonize national systems, the directive thus in effect extends them into their European environments. ${ }^{32}$

Supranational coordination does oblige national systems to make institutional amendments, its commitment to the preservation of national diversity notwithstanding. But given precisely that diversity, the impact of supranationally mandated change on national institutions must differ between countries. European works councils mean different things when implanted in the institutional environments of, say, Britain as compared to Germany, and integrating them in these requires different adjustments. As the British domestic debate on European works councils shows, there is even a possibility that European legislation may set in motion changes far beyond what would have been its original intentions. But as such changes result from the grafting of a new "European" institution on existing national institutions, they are at least as likely to be conditioned by the latter as by the former.

Functional equivalence. The main difference between harmonization and coordination in multilevel industrial relations is that the former suspends internal regime competition while the latter does not. As pointed out, regime competition is likely to give rise to-uncoordinated-adaptive change in national systems. Just like supranational coordination, the market pressures that issue from regime competition operate on highly heterogeneous initial conditions. Harmonization by market forces, through the adoption by all member countries of a single "best practice" model of industrial relations, therefore seems as improbable as harmonization by international institutional mandate. Very likely, successful adjustment to the new competitive conditions, even to the extent that these are in fact the same for all countries, will require different, "functionally equivalent" responses depending, above all, on countries' initial institutional endowments. Here, too, change tends to be path dependent and to preserve institutional diversity. ${ }^{33}$ 
Still, the simultaneous operation upon national systems of both supranational institutional pressures for coordination and international market pressures for competitiveness raises the issue of cross-national convergence. This, of course, is an old theme in the comparative study of industrial relations. Its origin lay in the postwar period and in the practical question of whether "free collective bargaining," one of the core principles of the American New Deal, could be successfully transplanted to the defeated nations of Europe and Asia or might even arise there spontaneously with the progress of "industrialism." 34 Comparative research, especially in the 1970s and 1980s, rejected the received "convergence theories" of the 1950 s by pointing to persistent institutional differences between countries. ${ }^{35}$ But what was easily overlooked was that such differences, politically and economically important as they were, were differences within a family-that of "Fordist" industrial relations systems; they existed, and indeed were identifiable, only on the background of equally important commonalities. ${ }^{36}$ One lesson from this debate for the study of industrial relations in the European Union is that differences in national industrial relations systems can be properly understood only in the context of their interaction with general tendencies-in the present case, with a changing overall relationship between markets and institutions in Europe's multilevel polity.

Functional convergence: Competitiveness as a hegemonic concept. Given capital's new exit options, national industrial relations in all European countries alike seem to be becoming more voluntaristic and less obligational, in the sense that unions and governments are relying less on sanctions and more on incentives to get concessions from employers. ${ }^{37}$ The increased bargaining power of capital that is behind this is reflected in the governance of employment relations becoming more pro-competitive, in that material rewards for workers and institutional influence for labor are more than before tied to the acceptance of a joint commitment with employers to success in competitive markets. This does not necessarily make European industrial relations labor exclusive in a structural sense; what is far more radically changing than their-nationally divergent-structures are their functions. Today the majority of European employers, rather than trying to exclude organized labor, seem to be content with changing the terms of its inclusion, by lowering the costs of such inclusion and increasing its returns. While the former is done through all sorts of concession bargaining "in the shadow of exit," the latter involves utilizing existing institutions of industrial relations as substructures of intensified communication and cooperation in the workplace, saving firms the costs of building such structures on their own and enabling them to benefit from past, often involuntary investment in "social consensus." To the extent that on balance labor inclusion still causes costs, these are pragmatically compared to the probable costs of a conflictual transition to managerial unilateralism - costs that, again, differ between countries as they depend largely on labor's institutionalized strength. 
In the process, a new European "peace formula" between capital and labor seems to be emerging that is gradually taking the place of the postwar formula of full employment and continuous income growth at constant distribution. ${ }^{38}$ In its stead it emphasizes the sharing of economic risk and responsibility in a less predictable environment and the joint search for "win-win" strategies in competitive markets. With a slight exaggeration it would appear that, while in the past industrial relations was about negotiating a secure status for workers and unions, insulating these from economic fluctuations, in the national industrial relations systems of today-deeply enmeshed in competitive international markets as they are-it is about adjusting the governance of the employment relationship to the imperatives of joint competitive success.

That European employers are for the time being not inclined to seek competitiveness through labor exclusion is in part because of the uncertain risks of industrial conflict, given the strength many European unions continue to derive from the national institutions of the postwar period. It may, in addition, reflect certain consensus requirements of high-performance work organizations. But clearly it is also because unions in almost all European countries are more or less willing to subscribe to the new peace formula, if only to prevent restructuring for competitiveness proceeding without them. As competitiveness rises to the status of a "hegemonic concept" in European industrial relations, ${ }^{39}$ employers are willing to take unions along on the road to restructuring, at both the national and company levels, sometimes supported by labor-inclusive supranational policies and institutions and sometimes not. While the functional requirements of joint competitiveness may not always be entirely clear, as long as unions are willing to accept the principle that labor-inclusive industrial relations are premised on competitive restructuring, European employers seem to be prepared not to draw the usefulness of labor inclusion into question.

The socialization of privatized social protection. One long-term consequence of the competitive restructuring of national industrial relations seems to be that their capacity as sources of social protection is declining. As unions internalize the imperatives of competitiveness, and firms are less able or willing to devote resources to purposes other than the pursuit of competitive success, work rules that place a ceiling on employee effort are disappearing or remain unenforced. So are solidaristic wage regimes that, for the sake of reducing inequality, overpay workers at the lower end of the wage scale while underpaying them at the upper end. Similarly, as firms eliminate slack to make themselves "fit for competition," employment regimes are waning that provided niches for less productive workers, were tolerant of a moderate degree of overmanning, and were less than perfectly sensitive to changes in demand, thus generating employment, and employment security, somewhat above and beyond what "the market" required.

With consensual restructuring largely eliminating social protection from the negotiated responsibilities of the firm, unions apparently continue to be able to 
express and protect the interests of core workforces, for example, but not exclusively in training or in high wages. At the same time, the competitive downsizing of firms and an increasingly lean organization of work externalize many of the protective functions that used to be performed by Fordist industrial relations and turn them over to society at large and to the social policy of the state. In the process, a rising number of people-from the long-term unemployed to the new self-employed-are disappearing from the constituency of the unions, which are becoming increasingly preoccupied with moderating the cooperation between a well-protected but numerically declining high-performance workforce and its employers.

As the resources available for public social policy decline, in part due to the same competitive market pressures that are transforming the workplace, and in part to internationally enshrined commitments to deficit reduction and "sound money," so does the capacity of national states to subsidize consensus in the workplace by providing for the growing number of people that a "leaner and meaner" high-wage economy can no longer employ. Again, how countries will respond to this will differ according to, among other things, different starting conditions. All of them, however, must find ways of restructuring their social welfare expenditures in line with the need to make their economies more "competitive"-in product markets, but perhaps even more in factor markets. This may require potentially profound changes, if not in spending levels, then in funding methods-changes that shift the burden from potentially mobile employers to more stationary workers and consumers. ${ }^{40}$ As the number of "good jobs" in the economy continues to decline, along with the ability of the state to retire surplus labor at a high level of wage replacement, a political space opens up for reforms of the welfare state that in effect lower the bottom under the labor market by promoting new forms of, more or less socially protected, low-wage employment.

Declining institutional capacities. Tendencies of convergence and divergence among national industrial relations systems in multilevel Europe thus appear interlocked in a complex pattern. Accelerated functional convergence under the pressure of regime competition-that is, growing functional equivalencecoincides with slow structural convergence, if at all, due to the stickiness of national institutions and the limited intervention capacities of supranational governance barred from harmonization and restricted to coordination. As functional diversity declines while structural diversity by and large persists, the significance of national institutions of industrial relations for the markets they are to govern must also decline. One upshot seems to be rising internal diversity within national systems, reflecting the weakened capacity of national institutions to override market forces and impose a common national pattern of economic governance on sectors, firms, and regions. Since this affects countries asymmetrically-those with strong institutions more than those whose institutions were always weak in rela- 
tion to market forces-the result is indeed some sort of convergence, with diversity between countries declining due to an increase in diversity within them.

Voluntarism and its new peace formula of joint competitiveness may well be seen as a convergent European "best practice model" of industrial relations, and frequently they are. But the common element of the national industrial relations systems separately moving in this direction is rather that, continuing structural differences notwithstanding, they are all losing their grip on the market forces they were once designed to control. Indeed, this is the way it should be in a process of economic liberalization. Where the new "European model" originates is not in social institution building but in an expansion of market relations. Institutional diversity, staunchly defended in the name of cultural diversity, not least by the advocates of "healthy competition" between institutions and "best practice benchmarking," remains strong enough to stand in the way of structural harmonization and system building at the European level. At the same time, it is increasingly less able to prevent functional convergence on a market-accommodating, more "flexible" model of the employment relationship. It is not by accident that, in this respect as in others, the transformation of the national institutions governing the labor market resembles that of the nation-state in which the former remain firmly embedded.

Social protection in embedded national systems. In the absence of supranational alternatives, national politics and industrial relations remain the privileged site for reregulatory responses to market expansion. This is irrespective of the fact that national systems in today's Europe must operate simultaneously under the institutional constraints of a supranational competition regime and the economic constraints of international regime competition. National industrial relations in particular find themselves embedded in a nation-state that has turned over some of its economic governance capacities to supranational institutions while others have altogether wasted away, and in an international market that tends to reduce national institutional differences to functionally irrelevant cultural idiosyncrasies. As pointed out above, there is no reason to believe that this will with functional necessity lead to a recovery of reregulatory capacity at the supranational level. All it may mean is that a realistic assessment of the potential for social reregulation in the European multilevel polity must above all emphasize its limitations. ${ }^{41}$

With supranationalization of social policy and renationalization of economic policy equally unlikely in the internationally liberalized European political economy, it will above all be national industrial relations that will have to deal with the pressures for social reregulation that arise from the operation of an international market. Little is known as yet how this will affect them, not least since far too much effort has been spent on anticipating the growth of supranational institutions presumably taking over their functions. Two directions of change in national 
systems are likely to be observed concurrently-adjustment of interests to capacities and adjustment of capacities to interests-most probably in different combinations in different countries.

First, as nationally contained industrial relations in an international economy become more market driven, the balance in their concerns between commodification and decommodification of labor is likely to shift in favor of the former-with interests in social protection becoming redefined as interests in economic competitiveness and class interests being replaced with national interests. To the extent that such redefinition of interests can be sustained, the demands on social and economic policies become compatible with the institutional forms available for satisfying them. Nationalist redefinition of interests in an international economy may open up political opportunities, narrowly circumscribed as they may be, for unions and governments to negotiate social pacts with employers that play on the dialectics of efficiency and fairness in the gray zone between market making and market modification and on the uncertainty of the functional value of social integration in labor markets and employment relations.

Second, efforts are also likely to be made, within the range of the internationally possible, to defend the institutional capacities for social protection of nationally contained industrial relations systems ${ }^{42}$ Inevitably, such efforts must involve modifications of the "four freedoms"- of the movement of goods, labor, capital, and services-that constitute the integrated European market. With growing demands for social protection, unions and governments in particular will be pressed to search both for national policies capable of insulating national reregulation from international and supranational constraints, as well as for supranational policies protecting national reregulation. Here, the complex, contested, and largely unexplored dynamics of the multilevel European polity may offer as yet unknown opportunities for political innovation.

Just as the systemic weakness of national industrial relations in an international market is no guarantee for their replacement with supranational industrial relations, the fact that there will be no supranational social protection in Europe does not mean that national social protection will suffice to prevent social instability. Indeed, a good deal of social destabilization- "flexibility"-is part and parcel of the liberalization program that is at the heart of European integration as we know it, and to this extent the political risks that come with it are incurred deliberately. Whether the much reduced level of stability and security that a nationally fragmented system of social protection can at most provide will be enough to sustain the legitimacy of the European political order is far from certain. But then, how much inequality and insecurity European societies are willing and able to live with and for how long, lowered as their expectations are by the pressure of international markets and the demise of their postwar political defenses, is a practical question that is not for the social scientist to answer. 
THE CONTINUING IMPORTANCE OF NATIONAL INDUSTRIAL RELATIONS IN INTEGRATED EUROPE

The following five examples illustrate diverse facets of the emerging new relationship between the national and the international in European industrial relations. In line with the logic of international liberalization, all point to the continuing primary importance of the national level, with respect to both the definition and the processing of collective interests in the expansion as well as the correction of markets. They also indicate profound changes in the operation of national industrial relations, stemming from the new institutional environment of multilevel politics and the impact of international markets and supranational coordination. In addition to demonstrating various aspects of the interaction of national institutions with demands for social protection-in the presence of competing national institutions located in the same market and of supranational institutions regulating national ones-they also show that the task of theorizing the complexities of multilevel industrial relations in Europe still remains to be resolved.

1.By far the most important event for European industrial relations in the past two decades was the Maastricht Treaty on Monetary Union and the subsequent Stability Pact. While both impose stringent requirements of financial orthodoxy on national economies aspiring to participate in Monetary Union, meeting these is considered an exclusively national affair. In effect, the treaty charges national governments with creating the domestic conditions for a stable austerity policy and overcoming whatever political resistance may arise. In a number of countries, this has led to more or less explicit alliances between the government, business, and labor aimed at "making the country fit for Monetary Union," with internationally instituted monetarism bringing about a surprising resurgence of national tripartite concertation. ${ }^{43}$

The mechanism behind this is simple but powerful. Once the liberal international order that is at the heart of European integration takes shape, it becomes an almost irresistible economic and political imperative for countries not to be excluded from it. Fulfilling the requirements of participation and survival in the integrated European economy may then turn into a national interest strong enough to override conflicting class interests. As the political-economic adjustments member countries have to undertake are considered their "homework," the incentives for national governments to try to build domestic coalitions around objectives of national competitiveness and modernization are considerable. So are the incentives to participate even for those groups in society, like labor, that are asked to make particularly large sacrifices.

Conforming with the ideological notion of "subsidiarity," the selective centralization of functional responsibilities under the Maastricht Treaty ensures that the main political capacities in integrated Europe remain those of national states exposed to competitive markets. Political action thus remains overwhelmingly 
national action, even in an international market and, paradoxically, as the result in part of international political agreements. But while the primary importance of national political arenas, interests, and identities in integrated Europe is confirmed, if only by default, the possible outcomes of national politics are limited by tight economic and institutional constraints that prescribe "convergence" on a wide range of issues, from inflation rates and the size of the national debt to, for example, the organization of telecommunications services. The perennial debate whether the national state and national politics gain or lose in importance as a result of European integration ${ }^{44}$ is thus resolved in a surprising way: both are true at the same time.

The strategy of imparting a liberal bias to the integrated European political economy by reinforcing the responsibility for it of national politics works even in areas where the potential for substituting competitive national interests for conflicting group interests is limited. For example, as long as the management of unemployment continues to be considered, in the sense of the Essen agreement, as a Hausaufgabe (homework) of national governments acting under international institutional and market constraints, the privileged means for it is to increase labor market "flexibility." International coordination of national employment policies, as envisaged under the Treaty of Amsterdam, will therefore in all probability mainly strengthen pressures for national deregulation, adding to identical pressures that have for some time been emerging from the Organization for Economic Cooperation and Development or the Group of Seven.

2.Once Monetary Union will be in place, the common currency will be operated in an economically extremely diverse labor market with little interregional mobility, and the European Central Bank will be faced with a highly organized but extremely - nationally - fragmented system of wage setting. ${ }^{45}$ From the perspective of the bank, a deunionization of the European economy on the American model must seem as unlikely as supranational centralization of wage negotiations. While the former would enable the European Central Bank, somewhat like the Federal Reserve in the United States, to tolerate a high employment level without having to be afraid of inflation, the latter would at least in theory offer the possibility of concerted wage restraint in exchange for an employment-oriented monetary policy - although without an economic government at the European level, this would be unlikely enough. But given the absence not only of employer interest, but also of supranational union capacity in the face of enormously heterogeneous national economic conditions, centralization of collective bargaining in Europe is not a realistic perspective. As a consequence, the European Central Bank will find itself in the worst possible position with regard to the support for monetary stability it can expect from the collective bargaining system. Its monetary policy will therefore for the foreseeable future remain restrictive.

Given the nonaccommodating policy that can be expected from the European Central Bank, the main problem of fragmented wage setting under Monetary 
Union will not primarily be inflation caused by "irresponsible" competitive bargaining inside nonencompassing bargaining units, as was the case in noncorporatist political economies in the $1970 \mathrm{~s} .{ }^{46}$ Rather, it will be whether unions in lowwage and low-productivity countries will manage to prevent their members, especially those employed in multinational companies, from insisting on equal pay -in the much more comparable common currency-with workers in highwage and high-productivity economies. This is because attempts in a low-wage country at correcting "unfair" wage differentials are likely to result in a rise in national unemployment. As this might undermine the support of the national government, it would exacerbate the pressure for institutional reforms making the national labor market more "flexible." Alternatively, national governments in low-wage countries might try to invoke national solidarity to get unions to fend off member demands that are satisfied only at high economic, social, and political costs. (Vice versa, unions in countries with high wages will continue to encourage invidious comparisons by workers in countries with lower wages, trying to defend their own employment opportunities by persuading potential competitors, in the name of international solidarity, to "price themselves out of the market.") National decentralization of political responsibility for the employment consequences of supranational monetary policy may thus result in unions entering into wage-moderation alliances with national governments concerned about the political costs of further increases in unemployment.

3.Passage of the European Works Councils Directive of 1994 is widely considered a breakthrough in the formation of a European industrial relations system. ${ }^{47}$ But there is also general agreement that the directive was possible only because it refrained from attempting to "harmonize" national systems of workplace representation. Indeed, all the directive does is create a mandate for member countries to oblige multinational firms based in their jurisdiction to extend a minimum of participation rights to workforces in subsidiaries located in other member countries. That minimum is identical throughout the European Union, although it is itself negotiable among managements and workforces in individual firms. But as the national systems to which European works councils are added remain as they are, the actual status of European works councils within their firms is bound to differ strongly between countries. ${ }^{48}$ Indeed, empirical research has found that the structures and rights of European works councils tend to be heavily influenced by the industrial relations system of their company's country of origin. ${ }^{49}$

European works councils are best understood not as general European institutions but as international extensions of national industrial relations systems that continue to remain distinctly different. ${ }^{50}$ Reinforcing such difference is the fact that, rather than being regulated by law, the details of European works councils are worked out through negotiation between the central management of a company and a delegation of its multinational workforce. It is not surprising that among the latter, the representatives of the company's home country workforce have been 
found to play the leading role. Indeed, just as central management tries to fit the European works council into the firm's - nationally colored-corporate culture, home country unions tend to treat the new institution as a means of extending their reach beyond their respective national borders. How this is done depends, again, on the structure of the national industrial relations systems involved, for example, on whether these have dual- or single-channel representation and on the degree of interunion competition. Nonetheless, national unions seem to be generally confident that they will be able to devise "their" European works councils in the image of their own national model of industrial relations and help them retain control in and over them.

Similar observations can be made with respect to the impending resolution of the decades-old political deadlock over workforce representation under European company law. The arrangement proposed by the Davignon Commission of Experts in the spring of 1997 may ultimately be acceptable in member countries because it limits access to European company law to firms that significantly "Europeanize" their operations. By thereby foreclosing such access to the vast majority of firms, at least for the time being, it leaves national systems of industrial relations intact. In particular, legal emigration on a broad scale from national company law with strong workplace participation rights to European company law with, inevitably, weaker rights is prevented or postponed in order to assuage especially German concerns over the short- and medium-term stability of the national co-determination system.

Further protecting the primacy of national systems is the fact that the exact structure of workplace representation in the European company is to be negotiated case by case. In such negotiations, the national workplace participation rights in the countries where a European company's constituent units are based are likely to serve as both political resources for the parties to the negotiation and baselines for an eventual settlement. At present, this seems to give unions like the German ones the confidence that they will be able to impose effective codetermination arrangements on European companies that grow out of the German system or have significant German elements, or at least to make such companies guarantee the acquis sociale in their national subentities. Still, like the European works councils, the negotiated character of company-level workforce participation under the Davignon model would imply a wide variety of company-specific hybrids of national systems rooted in national regimes and extending these, in nationally specific ways, beyond their borders.

As under both the European Works Councils Directive and the proposed participation arrangement for the European company, national systems of worker representation remain formally unchanged, and the pressure of regime competition on them continues in principle unabated. In the absence of harmonization, managements continue to be able to threaten to relocate production to European countries with weaker participation rights, where workforce representatives can 
be more easily persuaded to make concessions. Moreover, the negotiation of company-specific representation arrangements will inevitably be subject to imperatives of competitiveness. At the same time, the possibility of extending national industrial relations regimes internationally through custom-made arrangements within individual firms may take some of the edge out of regime competition, balancing part of the pressures on national systems to adapt to a more competitive international environment by endowing them with a however limited capacity to adapt that environment to themselves. ${ }^{51}$

4.The Social Protocol that was appended to the Treaty of Maastricht gave the organized "Social Partners," business and labor, a formal role in social policy legislation at the European level. ${ }^{52}$ By some, the creation of the co-decision procedure was regarded as a smart move of an activist European Commission seeking to put pressure on a council unable or unwilling to agree on meaningful social policies. ${ }^{53}$ Others attributed the event to a shared desire of unions and employers to appropriate between them a policy area that they knew better than the council and commission, providing themselves with an institutional capacity to discover common interests and prevent incompetent intervention by supranational and intergovernmental bodies ${ }^{54}$ In either view, as a bureaucratic tool or as a result of joint assertion of a right to industrial self-governance, the procedure appeared as a new kind of corporatist structure at the European level, adding to the array of supranational and international institutions that, presumably, were about to supersede national social policy and industrial relations.

None of these interpretations sits well with the fact that, since it came into force in 1993, the co-decision procedure produced no more than two agreements, one on parental leave ${ }^{55}$ and another on part-time work, ${ }^{56}$ neither of which seems to have made a discernible difference for the legal order of only a single-member country. Received explanations for this point mostly to the difficult politics of institution building in integrated Europe ${ }^{57}$ The lack of substance of the parental leave agreement is usually attributed to a need to use an uncontroversial subject to try out and establish the new institution. Similarly, the agreement on part-time work is said to have served to impress the Intergovernmental Conference of 1997, which needed to be convinced to continue the procedure and incorporate it fully in the treaty. While this assumes unions and employers to have identical institutional interests, the meager outcome of their negotiations may also reflect a compromise between unions trading concessions on substance in return for employers accepting the principle of European negotiations and employers making concessions on principle in return for pro forma European legislation putting to rest potentially uncomfortable policy issues. ${ }^{58}$

In the European Union, symbolic politics is always a possibility. It is also conceivable that apparently irrelevant European-level regulations may in fact be designed to prevent countries from lowering their standards in the future. But as time passes, and in view of the continuing absence of a meaningful legislative 
agenda for the co-decision procedure, other hypotheses begin to offer themselves. Unthinkable in the functionalist world of mainstream integration theory, the creation of the co-decision procedure may have served not to expedite supranational social policy but to relieve the commission and council of an intractable set of issues, by moving these to a less politically exposed new arena. There it may have been received especially by the employers not as a welcome opportunity to develop a corporatist social partnership at European level but as an arrangement returning social policy to unanimous decision making - this time between the social partners-at the very moment when in the council it was partly coming under qualified majority voting. The institutionalization at Maastricht of the Social Dialogue in the form of the co-decision procedure would thus have amounted above all to a restoration of the veto in social policy, to be wielded not by nation-states but by organized employers concerned about a potential social policy activism of European political bodies.

This still leaves open the question of how the co-decision procedure works in practice and exactly where the interests of unions and employers are likely to meet in the everyday operation of the new arena given the way it is constituted. Here one may surmise that the main actual functions of the post-Maastricht Social Dialogue, apart from its contribution to the organizational development of the European peak associations, Union of Industrial and Employers' Conference of Europe and European Tade Union Confederation, relate to the emerging relationship between national and international industrial relations in integrated Europe. More specifically, the modal type of measures that the Euro-corporatist machinery may be poised to generate may be one that protects the institutional and political equilibrium of the national systems of capital-labor relations by sterilizing supranational policy with respect to its possible institutional consequences at the national level.

One central aspect of institutional diversity in integrated Europe is that in some countries, certain social policy issues are dealt with by legislation whereas in others they are regulated by agreement between the social partners. ${ }^{59}$ Where the latter is the case, employers and unions must equally be concerned about the prospect of European regulation taking bargaining matters out of their hands, especially where issues are significant for the national give-and-take and the balance of concessions between the two sides. Close involvement of the "social partners" in European social policy making, represented by organizations that in turn represent national peak associations, may be the best way of protecting national corporatist arrangements from a possible etatistic bias on the part of the commission and, in particular, the members states sitting in the council.

Regulation by agreement between the social partners at the European level offers the affiliates of the European peak associations of business and labor an opportunity to block legislation that diminishes their standing and upsets their mutual relations in their respective national systems. It thus enables nationally 
organized interests to defend the institutions to which they have grown accustomed over a long time, especially against a Council of Ministers now potentially deciding with qualified majority vote. Euro-corporatism, rather than moving collective interests in economic governance to the supranational level, as suggested by traditional integration theory, would in effect safeguard the diversity of national institutions, especially the various and diverse national corporatisms. While on the surface serving no visible purpose, legislative measures like the directives on parental leave or part-time work may in fact defend the integrity of national institutional practices embedded in a multilevel political system.

5. The most telling illustration of the continuing primacy of national institutions in European industrial relations is perhaps offered by the Posted Workers Directive, which seems to be ideally suited for exploring the institutional capacities of European multilevel social policy ${ }^{60}$ Confirming their general weakness, it appears that a main reason why the directive ${ }^{61}$ could at all be passed was the prior existence of various pieces of national and international law relevant to the subject, which made the actual "value-added" of the directive much smaller than may seem at first glance. Observing this is not to detract from the formidable political skill that had to be brought to bear on the matter before the directive could finally become law. ${ }^{62}$ Quite to the contrary, the case shows that, even where a major member country and an extraordinarily knowledgeable and energetic council president put all their weight behind a legislative project, progress in European social policy at the supranational level depends on exceptionally favorable circumstances, and even where these exist remains confined to very modest amendments on the margins of already existing legal arrangements.

In particular, the Posted Workers Directive was passed on the background of a well-developed body of international private law, especially collision law, that had been created outside the framework of the European Union. In 1991, the Convention of Rome, which had been concluded as early as 1980, become legally binding on all European Union member states as a result of individual accession. ${ }^{63}$ By the time the Internal Market for services was completed, it was already an established principle that countries may make a wide range of social provisions binding on foreign firms posting workers on their territory. It may have been questionable whether such provisions included the national minimum wage, especially given the new freedom of competition in service provision after 1992. On the other hand, the posting of workers had in principle been possible in Europe since 1970, and the European Court of Justice had, in a number of decisions long before any directive had been proposed, ruled that European Union member countries have a right to enforce their "public order" on foreign firms that carry out work on their territory, regardless of whether their workers were employed under the law of a different member country. ${ }^{64}$ One such ruling in particular had, thirdly, paved the way for French legislation in 1993 and 1994, prior to the directive that was passed in 1996, which extended all generally binding collective agreements, 
including wage agreements, to all workers on French territory ${ }^{65}$ Whatever the directive added to the regulation of employment in Europe was added against and to this background.

Apart from this, the Posted Workers Directive seems to have been successful mainly for two reasons. The first was that it managed to turn the issue of protection for workers and social regimes in high-wage countries into one of equal protection for posted workers from low-wage countries and, simultaneously, of fair competition among domestic and foreign firms. With respect to the former, the directive obliges member countries to ensure that posted workers are not paid less than what national workers are entitled to. With respect to fair competition, the directive allows countries to require nonnational firms to pay a national minimum wage to posted workers only if the same requirement applies also to domestic firms-thus protecting foreign firms from being bound by rules that do not equally bind their domestic competitors, but also protecting domestic firms from having to follow rules that do not also apply to their foreign competitors. Put differently, what the directive prohibits is for a country to have a binding minimum wage and not extend it to posted workers, as well as to impose a minimum wage on foreign firms that is not also binding on national firms and vice versa. While on the surface this is defined as a matter of equal treatment for both workers and firms - or of mobility of labor and fair competition - in effect it allows high-wage countries to limit the competitive advantage of foreign firms and thereby protect their own acquis sociale.

Otherwise, however, the directive strictly refrains from intervention in the internal affairs of national systems of industrial relations and social protection, and this seems to be the second main reason why it was ultimately successful. How a binding minimum wage is set and enforced, whether by industrial agreement or by legislation, is for countries themselves to decide, and so is the level of that wage. Even more important, while countries are allowed under the directive to have an obligatory minimum wage-and are then required to extend it to posted workers to ensure both equal treatment and fair competition-they are also allowed not to have one, in which case foreign firms pay their posted workers what they have to under their national conditions, provided such conditions exist. While the directive does restore, or preserve, a national capacity for social regulation within an international environment of liberalized markets, it does so only by not forcing receiving countries to let employers of posted workers pay these less than what domestic employers cannot avoid paying; what a country makes of this, if at all, is exclusively its national affair. Rather than a common supranational floor under the common international market, social protection of this sort consists of a set of nationally specific arrangements member countries may choose or not choose to have, depending on what their internal political process supports and provided its terms and conditions are compatible with the "four freedoms" of the integrated market. Countries that prefer to have their social structures driven 
by market forces cannot be prevented from acting accordingly, even if this may place more socially regulated countries at a competitive disadvantage.

What the model of supranationally vindicated but nationally instituted social protection that is exemplified by the Posted Workers Directive can accomplish is a matter of considerable interest. Instead of setting identical standards for the integrated European market, supranational social policy of this sort merely preserves the option for countries to create nationally specific social rights (that they must then extend also to nonnationals). Given the wide range of differences in national politics and institutions within Europe, such rights are bound to vary between countries, exposing them to regime competition. Moreover, as the international institutions that envelope and regulate national polities and industrial relations offer new and very likely asymmetrical constraints and opportunities to the domestic actors among which social protection must be negotiated, they are likely to change the equilibrium within national systems, making the outcome of national efforts at reregulation less than predictable.

How this may work is shown by the German case. ${ }^{66}$ German construction wages are among the highest in Europe, which raises the stakes for the buyers of construction services in market liberalization. Moreover, unlike France, the German system knows no legal minimum wage, and in any case the liberal party in the government coalition would not have agreed to one. Wages in Germany are set by industrial agreement. Although coverage is extensive, it remains in principle possible for employers not to join an employers association and thereby remain outside the agreement. While agreements may be declared generally binding by the Minister of Labor-which makes them apply also to employers not affiliated to the respective employers association-this requires the consent of the peak associations of both business and labor. Also, it is usually not done for wage agreements.

On this background, all the German legislator was able to come up with was a law obliging foreign construction firms to honor German wage agreements, provided that these had been declared generally binding.$^{67}$ This gave an opening to forces interested in low construction prices, or in liberalization of the German economy in general, which lobbied the Federation of German Employers Associations (BDA) to veto the Allgemeinverbindlichkeitserklärung of the construction industry wage agreement. Had they prevailed, Germany would not have been able to set a binding minimum wage for construction workers that would have satisfied European law; it would as a consequence have had to allow foreign construction firms to pay their posted workers on their own terms.

After long and contorted negotiations with the employers, the government, and, indirectly, the BDA, the German construction union did get its wage agreement declared generally binding. But for this it had to accept insertion in it of a low-wage category, split between West and East Germany and considerably below the lowest wage in the old agreement. ${ }^{68}$ Originally, this category was to be 
limited to posted workers, who would thus have been paid more than in their home countries but less than German workers. As arguably this constituted discrimination on the basis of nationality, it would probably not have survived a legal test. But this aspect of the matter has already become moot since, as might have been predicted, growing numbers of-mostly unskilled-German workers are being assigned to the new category, especially in the East where a majority of employers have abandoned or never joined employers associations or have long disregarded the agreement signed by the latter on their behalf.

European law of the kind of the Posted Workers Directive does allow a national reregulatory response to the social consequences of market liberalization. But especially in a high-wage setting like Germany, where social protection is more expensive than in competing countries, this may not be nearly enough for preserving the old regime. While national political capacities were sufficient to prevent full liberalization, significant concessions had to be made. The demanding European conditions for national reregulation to be compatible with market freedoms offered proponents of liberalization new opportunities that shifted the balance of power in their favor, above all by giving them a veto over the setting of a minimum wage recognized as binding under European law. Continuing differences in construction prices in European countries keep alive the interest of the users of construction services in Germany in strong international competition, hoping for lower costs and an improved competitive position in their own product markets. At the same time, the power of German unions to defend their established wage regime by strike is weakened by increased market access of foreign firms whose workforce they are unable to organize, at a time when high unemployment, especially in the East, has already severely undermined union capacity. Having to be reconstructed under these conditions and in accordance with the liberal competition regime of the Internal Market, the institutional order of the German construction sector is bound to change significantly, even though it does not have to disappear altogether.

\section{CONCLUSION}

National industrial relations in Europe are not about to be absorbed into supranational industrial relations. Supranational institutions of capital-labor relations will continue to develop but more as extensions of rather than substitutes for national institutions. Structural diversity between the latter will persist, constituting an effective roadblock to supranational harmonization. But the changed institutional environment of national industrial relations systems, including in particular the loss of monetary and fiscal policy capacity on the part of European nation-states, will change the modus operandi of national systems, and so will regime competition in the integrated international market. In the process, the capacities of national systems to override and correct market forces will diminish, in the longer run very probably leading to growing structural diversity within 
national systems as well as increasing functional convergence between them, with a new "peace formula" emerging between capital and labor that emphasizes joint interests in national or company competitiveness.

Pressures for social reregulation of the employment relationship will continue to arise in spite, and indeed as a consequence, of international liberalization. Absent suitable receptacles at the supranational level, such pressures will have to be accommodated mostly by national regimes of industrial relations and social policy. Given the changed institutional and economic conditions under which these must operate, demands for social reregulation will tend to be articulated in terms of the social preconditions of competitive efficiency - their chance of being heard increasing with the estimated economic costs of discontent and with the perceived uncertainties in the operation of socially uncorrected markets. The politics of the market-embedded national industrial relations systems of integrated Europe will thus amount to an exploration of the social limits of liberalization and the minimum social requirements of a stable market economy-of the concessions capital has to make in an internationalized market in exchange for national cooperation and social peace. In the process, new alliances will emerge within and across classes, which will likely differ from country to country.

In the absence of realistic possibilities for pushing social reregulation upwards to the supranational level, its prospects depend on a rebuilding under the new conditions of national capacities for market correction. In integrated Europe, this requires supranational license and, perhaps, facilitation, with European coordination of structurally diverse national systems representing the most important tool for putting a brake on market-driven functional convergence. Industrial relations always served purposes of both market making and market correction. But in the market-embedded national industrial relations systems of the European Union, the balance between the two is bound to shift in favor of the former and away from the latter. As illustrated, the comparatively modest reregulatory responses that the fragmented industrial relations of integrated Europe supports include, or may be included in, tripartite national modernization coalitions that, under the Economic and Monetary Union, may turn into national wage moderation alliances; the building of coordinating institutional interfaces between national systems, like the European works councils; the safeguarding of national patterns of interest politics through their expansion into the European arena, as in the Social Dialogue; and the use of European legislation to enable member countries to protect their social structures from destabilization by the international competition regime that is the heart of European integration.

Future research and, even more so, future political praxis will have to establish the true potential of national reregulatory responses to international liberalization. Recognition of their inherent limitations should not blind one to contradictory tendencies or potentially significant national and sectoral variations. Again, the example of the German settlement of the posted workers issue appears instructive. 
While the union had to accept a considerable lowering of the old minimum wage as established by industrial agreement, the combined effect of the Posted Workers Directive, of the German law passed simultaneously with it, and of the declaration of the new wage regime as generally binding ensures for the first time that all construction firms in Germany, in the employers association or out, have to pay a legally enforceable minimum wage. Undoubtedly by the old standards, this wage is low. But it does apply also to the large number of firms in East Germany that had for long ceased to abide by the collective agreement, paying their workers even less than what is now, after the European developments, the legally binding minimum. While the grand picture may be clear, its details justify careful inspection as they offer interesting variety and, sometimes, productive surprises.

\section{NOTES}

1. Ernst B. Haas, The Uniting of Europe: Political, Social and Economic Forces 1950-1957 (London: Stevens \& Sons, 1958).

2. Pace the "spillover" theories of practicing neo-functionalists from Monnet to Delors, who believed and still believe in state formation as an inevitable consequence of market integration, a practical theory that applies, if at all, only in a Shonfieldian world of "organized capitalism."

3. European integration is not the only cause of the liberalization and internationalization of European economies, certainly not since the 1980s. But given its early established institutional logic, it is much better suited to reinforcing than to counterbalancing external or internal liberalization pressures.

4. Wolfgang Streeck, "Public Power beyond the Nation-State: The Case of the European Community," in Robert Boyer and Daniel Drache, eds., States against Markets: The Limits of Globalization (London: Routledge Kegan Paul, 1996), 299-315. See also Bernhard H. Moss and Jonathan Michie, eds., The Single European Currency in National Perspective: A Community in Crisis? (London: Macmillan, 1998).

5. See Fritz W. Scharpf, "Negative and Positive Integration in the Political Economy of European Welfare States," in Gary Marks, Fritz W. Scharpf, Philippe C. Schmitter, and Wolfgang Streeck, eds., Governance in the European Union (London: Sage, 1996), 15-39. The same can be said for liberalization generally. In an interdependent international economy, for a country to stay aloof if others are liberalizing their markets is likely to be costly. In fact, it may be enough to make all other countries liberalize if just one country does, like the United Kingdom in banking and telecommunications or the United States in labor relations during the 1980s. There are no comparable first-mover advantages in constraining markets; indeed, first movers are likely to be punished by "market forces." This asymmetry makes liberalization largely self-enforcing. See Adrienne Héritier, "Market-Making Policy in Europe: Its Impact on Member-State Policies: The Case of Road Haulage in Britain, The Netherlands, Germany and Italy,' Journal of European Public Policy 4, no. 4 (1997): 539-555.

6. Susanne Schmidt, "Commission Activism: Subsuming Telecommunications and Electricity under European Competition Law," Journal of European Public Policy 5, no. 1 (1998): 169-184. 
7. On Europe as a multilevel polity, see Fritz W. Scharpf, "The Joint-Decision Trap: Lessons from German Federalism and European Integration," Public Administration 66 (1988): 239-278. For a more comprehensive application of the concept, see Marks et al., Governance in the European Union, where the concept is, however, not used consistently by the authors.

8. Where the central level of governance is an international arena of intergovernmental relations, functionally limited to the implementation and regulation of an international market, while politics and the social control of markets remain decentralized in a set of nation-states under market pressures and international obligations not to obstruct free trade.

9. Steven K. Vogel, Freer Markets, More Rules: Regulatory Reform in Advanced Industrial Countries (Ithaca, NY: Cornell University Press, 1996).

10. Giandomenico Majone, Understanding Regulatory Growth in the European Community, EUI Working Paper SPS No. 94/17 (Florence: European University Institute, 1994).

11. T. H. Marshall, Class, Citizenship, and Social Development (Garden City, NY: Doubleday, 1964).

12. Karl Polanyi, The Great Transformation: The Political and Economic Origins of Our Time (Boston: Beacon, [1944] 1957).

13. Gosta Esping-Andersen, Politics against Markets: The Social Democratic Road to Power (Princeton, NJ: Princeton University Press, 1985).

14. Wolfgang Streeck, "Status and Contract as Basic Categories of a Sociological Theory of Industrial Relations," in Social Institutions and Economic Performance: Studies of Industrial Relations in Advanced Capitalist Economies (London: Sage, 1992).

15. Remember the way Jacques Delors argued for the "social dimension" of the European Union by reminding skeptical national governments that "one cannot fall in love with a market."

16. Gary Marks, Liesbet Hooghe, and Kermit Blank, "European Integration from the 1980s: State-Centric v. Multi-level Governance,” Journal of Common Market Studies 34, no. 3 (1996): 341-378, and Mark A. Pollack, "The New Institutionalism and EC Governance: The Promise and Limits of Institutional Analysis," Governance 9, no. 4 (1996): 429-458.

17. Jelle Visser and Bernd Ebbinghaus, "Making the Most of Diversity? European Integration and Transnational Organization of Labour," in Justin Greenwood, Jürgen R. Grote, and Karsten Ronit, eds., Organized Interests and the European Community (London: Sage, 1992).

18. On this, see the appendix to my chapter in Marks et al., Governance in the European Union.

19. Michael Gold, The Development of EC Social Dialogue, Working Paper No. 12 (London: National Institute of Economic and Social Research, 1992) and Manfred Weiss, "Social Dialogue and Collective Bargaining in the Framework of Social Europe," in George Spyropoulos and Gabriel Fragnière, eds., Work and Social Policies in the New Europe (Brussels, Belgium: European Interuniversity Press, 1991).

20. Jon Erik Dolvik, The ETUC and Development of Social Dialogue and European Negotiations after Maastricht, ARENA-Working Paper No. 2 (Oslo, Norway: Advanced Research on the Europeanisation of the Nation-State, 1997).

21. Michael Gold and Mark Hall, "Statutory European Works Councils: The Final CountDown?" Industrial Relations Journal 25, no. 3 (1994): 177-186, and Paul Marginson 
and Keith Sisson, "European Works Councils-Opening the Door to European Bargaining?” Industrielle Beziehungen 3, no. 3 (1996): 229-236.

22. Jacques Pelkmans, "The Institutional Economics of European Integration," in Mauro Cappelletti, ed., Integration through Law: Vol. 1. Methods, Tools and Institutions, Book 1: A Political, Legal and Economic Overview (Berlin: de Gruyter, 1985), 318-396.

23. According to which member states can delegate the national implementation of a European directive to the social partners, provided these can ensure that they can achieve the results the directive prescribes.

24. In other words, they reflect the fact that in integrated Europe, national industrial relations systems are horizontally linked to each other through market relations and vertically linked to a supranational system through institutional relations.

25. Richard McKenzie and David Lee, Quicksilver Capital: How the Rapid Movement of Wealth Has Changed the World (New York: Free Press, 1991); Vivien Schmidt, "The New World Order, Incorporated: The Rise of Business and the Decline of the NationState," Daedalus 124, no. 2 (1995): 75-106; John M. Stopford, Susan Strange, and John S. Henley, eds., Rival States, Rival Firms: Competition for World Market Shares (Cambridge: Cambridge University Press, 1991).

26. The possibility that increased chances of exit may make voice more effective has been pointed out by Hirschman in his analysis of the demise of the DDR. Albert O. Hirschman, "Abwanderung, Widerspruch und das Schicksal der Deutschen Demokratischen Republik," in Selbstbefragung und Erkenntnis (München: Hanser, 1995), 19-56.

27. Manfred E. Streit, "Dimensionen des Wettbewerbs-Systemwandel aus ordnungsökonomischer Sicht," Zeitschrift für Wirtschaftspolitik 44, no. 2 (1995): 113-134.

28. Gerda Falkner, “'Sozialdumping' im EG-Binnenmarkt: Betrachtungen aus politikwissenschaftlicher Sicht," Österreichische Zeitschrift für Politikwissenschaft 22, no. 3 (1993): 261-276.

29. On some of the functions and dysfunctions of regime competition in Europe, see Fritz W. Scharpf, Globalisierung als Beschränkung der Handlungsmöglichkeiten nationalstaatlicher Politik, MPIFG Discussion Paper 97/1 (Köln: Max Planck Institute for the Study of Societies, 1997).

30. Wolfgang Streeck, "From Market-Making to State-Building? Reflections on the Political Economy of European Social Policy," in Stephan Leibfried and Paul Pierson, eds., European Social Policy: Between Fragmentation and Integration (Washington, DC: Brookings Institution, 1995), 389-431.

31. For a general overview, see Mark Hall, Mark Carley, Michael Gold, Paul Marginson, and Keith Sisson, eds., European Works Councils: Planning for the Directive (London: Industrial Relations Services, 1995).

32. Wolfgang Streeck, Citizenship under Regime Competition: The Case of the European Works Councils, Jean Monnet Chair Paper 97/42 (Florence, Italy: European University Institute, Robert Schuman Centre, 1997). For more on this, see infra.

33. On the improbability of "best practice convergence," see J. Rogers Hollingsworth and Wolfgang Streeck, "Countries and Sectors: Concluding Remarks on Performance, Convergence and Competitiveness," in J. Rogers Hollingsworth, Philippe C. Schmitter, and Wolfgang Streeck, eds., Governing Capitalist Economies: Performance and Control of Economic Sectors (New York: Oxford University Press, 1994), 270-300. Also consider the succession of leading "national models" in industrial relations that other countries were supposed to emulate but never could or would: first the United States, then for a time "Modell Deutschland," later Japan, and now again the United States.

34. John Dunlop, Industrial Relations Systems (Carbondale: Southern Illinois University Press, 1958) and Clark Kerr, John Dunlop, Frederick H. Harbison, Charles A. Myers, 
and Roy Haddon, eds., Industrialism and Industrial Man (Cambridge, MA: Harvard University Press, 1960).

35. John Goldthorpe, ed., Order and Conflict in Contemporary Capitalism: Studies in the Political Economy of West European Nations (Oxford, UK: Clarendon, 1984).

36. This, incidentally, explains why the controversy between the proponents of divergence and convergence was never resolved: since both tendencies were simultaneously present, and had to be for the question to make sense in the first place, it all depended on which aspects of reality one was willing to include in the picture.

37. Franz Traxler, "Vom Nachfrage- zum Angebotskorporatismus?" in E. Tálos, ed., Sozialpartnerschaft: Kontinuität und Wandel eines Modells (Wien: Verlag für Gesellschaftskritik, 1993), 103-116.

38. On the postwar peace formula, see Stephen Bornstein, "States and Unions: From Postwar Settlement to Contemporary Stalemate," in Stephen Bornstein, David Held, and Joel Krieger, eds., The State in Capitalist Europe: A Casebook (London: Allen \& Unwin, 1984), 54-90.

39. Bastiaan van Apeldoorn, "Transnationalisation and the Restructuring of Europe's Socio-Economic Order," International Journal of Political Economy 28 (1998).

40. Fritz W. Scharpf, "Economic Integration, Democracy and the Welfare State," Journal of European Public Policy 4, no. 1 (1997): 18-36.

41. Daniel Drache and Meric Gertler, eds., The New Era of Global Competition: State Policy and Market Power (Montreal: McGill-Queen's University Press, 1991) and Susan Strange, “The Defective State," Daedalus 124, no. 2 (1995): 55-74.

42. Given the continuing importance of national sovereignty within the European multilevel system, this would appear to be more promising than supranational harmonization efforts. See Peter Behrens, "Die Konvergenz der wirtschaftlichen Freiheiten im europäischen Gesmeinschaftsrecht," Europarecht 2 (1992): 145-162 and Karen J. Alter and Sophie Meunier-Aitsahalia, "Judicial Politics in the European Community: European Integration and the Pathbreaking Cassis de Dijon Decision," Comparative Political Studies 26, no. 4 (1994): 535-561.

43. Martin Rhodes, "Globalisation, Labour Markets and Welfare States: A Future of Competitive Corporatism?" in Martin Rhodes and Yves Mény, eds., The Future of European Welfare: A New Social Contract? (London: Macmillan, 1997).

44. Alan S. Milward, The European Rescue of the Nation-State (Berkeley: University of California Press, 1992) and Andrew Moravcsik, "Why the European Community Strengthens the State: Domestic Politics and International Cooperation" (paper presented at the Conference of Europeanists, Chicago, May 1994).

45. On the following compare Peter A. Hall and Robert J. Franzese, Jr., Mixed Signals: Central Bank Independence, Coordinated Wage-Bargaining and European Monetary Union, unpublished manuscript (1996).

46. Colin Crouch, "Conditions for Trade Union Wage Restraint," in Leon N. Lindberg and Charles S. Maier, eds., The Politics of Inflation and Economic Stagnation (Washington, DC: Brookings Institution, 1985), 105-139.

47. Jean-Jacques Danis and Reiner Hoffman, "From the Vredeling Directive to the European Works Council Directive: Some Historical Remarks," Transfer 1, no. 2 (1995): 180-187 and Mark Hall, Legislating for Employee Participation: A Case Study of the European Works Councils Directive, Warwick Papers in Industrial Relations No. 39 (Warwick: University of Warwick, Industrial Relations Research Unit, School of Industrial and Business Studies, 1992).

48. Streeck, Citizenship under Regime Competition. 
49. Hubert Krieger and Pascale Bonneton, "Analysis of Existing Voluntary Agreements on Information and Consultation in European Multinationals," Transfer 1, no. 2 (1995): 188-206 and Pascale Bonneton et al., eds., Analysis of Existing Agreements on Information and Consultation in European Multinationals (Brussels, Belgium: European Commission, 1996).

50. Streeck, Citizenship under Regime Competition.

51. There is, in addition, the possibility of European union confederations at the intersectoral as well as the sectoral level, acting as promoters of institutional convergence by influencing the negotiations between management and labor on European representation arrangements at the company level. Establishing the importance of this factor requires detailed research.

52. This part of my argument is informed by current research by Ute Knaak.

53. John T. Addison and Stanley Siebert, "Recent Developments in Social Policy in the New European Union," Industrial and Labor Relations Review 48, no. 1 (1994): 5-27.

54. Bernhard Bockmann, "Das Verhandlungsverfahren nach dem Maastrichter Sozialpolitischen Abkommen," in Peter Oberender and Manfred E. Streit, eds., Europas Arbeitsmärkte im Integrationsprozeß (Baden-Baden: Nomos, 1995), 193-211.

55. See the annex of the Council Directive on the Framework Agreement on Parental Leave Concluded by UNICE, CEEP, and the ETUC, COM (96) 26 final 31.1.1996.

56. See the annex of the Proposal for a Council Directive on the Framework Agreement on Part-Time Work Concluded by UNICE, CEEP, and the ETUC, COM (97) 392 final 23.7.1997.

57. Gerda Falkner, "The Euro-Agreement on Parental Leave: Towards Corporatism in European Social Policy?" (paper presented at the 8th International Colloquium of Politiques et Management Public, Paris, June 20-21, 1996).

58. Bernd Keller and Bernd Sörries, "The New Social Dialogue: New Concepts, First Results and Future Perspectives" (paper presented at the 5th European Regional Conference of the International Industrial Relations Association, Dublin, Ireland, August 26-29, 1997).

59. Armin Höland, "Partnerschaftliche Setzung und Durchführung von Recht in der Europäischen Gemeinschaft," Zeitschrift für internationales Arbeits- und Sozialrecht 9 (1995): 425-451.

60. I am drawing here on work of Werner Eichhorst. "Posted workers" are temporarily sent ("posted") by their employer to a second country for work on behalf of their employer. Unlike migrant workers who take up employment in the country where they work, posted workers bring an existing employment relationship with them as they cross the border. In European law, the migration of workers is considered a matter of "freedom of movement" (which by now is basically unlimited within the European Union), whereas the posting of workers concerns the freedom for firms of service provision. Unlike migration, the posting of workers raises fundamental questions regarding the territorial integrity of national employment regimes: do workers who work in a given country have to be paid "the wage of the land," or can they be paid under an exterritorial labor regime under which they are legally employed? If the latter was the case, construction firms from low-wage countries such as Portugal could win contracts in high-wage countries by moving workforces that are paid Portuguese wages from the former to the latter, preempting national legislation and undermining collective bargaining in the receiving country.

61. Directive 96/71/EC of December 16, 1996, on the Posting of Workers in the Framework of Provision of Services, EC Official Journal L 18, p. 1ff, of January 21, 1997. 
62. Marco Biagi, "Fortune Smiles on the Italian EU Presidency: Talking HalfSeriously about the Posted Workers and Parental Leave Directives," International Journal of Comparative Labour Law 2, no. 2 (1996): 97-109.

63. Alain Desmazières de Séchelles, "Free Movement of Workers and Freedom to Provide Services," in Henry G. Schermers et al., eds., Free Movement of Persons in Europe (Dordrecht, the Netherlands: Nijhoff, 1993), 472-484.

64. ECJ Judgements Seco/Desquenne/Giral and Seco/EVI of February 3, 1982, Cases 62/81 and 63/81; ECJ Judgement Rush Portuguesa/OMI of March 27, 1990, Case 113/89; ECJ Judgement Vander Elst/OMI of August 9, 1994, Case 43/93.

65. Law No. 93-1313 of December 20, 1993. IDS European Report 397, January 1995, pp. 18-19.

66. See also Bernd Sörries, "Die Entsenderichtlinie: Entscheidungsprozeß und Rückkopplungen im Mehrebenensystem," Industrielle Beziehungen 4, no. 2 (1997): 125-149.

67. Gesetz über zwingende Arbeitsbedingungen bei grenz berschreitenden Dienstleistungen, February 26, 1996, Bundesgesetzblatt 1996, Teil I, Nr. 11 vom 29.2.96, pp. $227 \mathrm{ff}$. See Frank Lorenz, Arbeitnehmer-Entsendegesetz (AEntG)-Gesetztestext und Materialien (Baden-Baden: Nomos, 1996) and Peter Hanau, "Das ArbeitnehmerEntsendegesetz," Neue Juristische Wochenschrift 49 (1997): 1369-1373.

68. See various editions of European Industrial Relations Report (EIRR), especially No. 267, April 1996, p. 7; No. 268, May 1996, pp. 14-15; No. 269, June 1996, pp. 6f.; No. 271, August 1996, p. 6f.; No. 273, October 1996, p. 5. 